\title{
16. YÜZYIL ŞAİRİ HAYRETî'NIN YAYIMLANMAMIŞ İKİ GAZELİ VE BU İKİ GAZEL ÜZERINE DEĞERLENDİRMELER
}

\author{
Karden KARAKOÇ*
}

\begin{abstract}
Özet
16. yüzyıl, klasik Türk edebiyatının zirve isimlerinin yetiştiği bir dönemdir. Bu dönemin en büyük şairlerinden biri de Hayretî’dir. Vardar Yenicesi'nde doğan Hayretî, Mevlevî şeyhi Yûsuf-1 Sîneçâk'in kardeşidir. Mutasavvıf bir kişiliğe sahip Hayretî, önce Şeyh İbrahim Gülşenî’ye intisap etmiş daha sonra da Bektaşîliği benimsemiştir. Ömrünün sonuna doğru gözlerini kaybeden Hayretî’nin mürettep bir divanı vardır. Hayretî Divanı'nı Mehmet Çavuşoğlu ve M. Ali Tanyeri yayımlamıştır. Tezkire yazarlarının değerlendirmelerine göre âşıkane, halk zevkine uygun, sade ve hoşa giden gazelleri olan Hayretî’nin şiirlerine pek çok mecmua ve kısmen de cönklerde rastlamak mümkündür. Bu şiirlerden bazıları şairin divanında mevcutken bazıları ise şairin divanında yoktur.

Şair tezkireleri, tarihi ve biyografik kaynaklar tarandığında 16. yüzyılda yaşamış başka Hayretî mahlaslı bir divan şairine henüz rastlanmamıştır. Milli Kütüphane 06 Mil Yz A 3291 numaralı şiir mecmuasında Hayretî mahlasıyla kayıtlı 28 gazel bulunmaktadır. Bu gazellerden 3'ü Mehmet Çavuşoğlu ve M. Ali Tanyeri'nin hazırladığı Hayretî Divanı'nda bulunmamaktadır. Hayretî Divanı'nda bulunmayan 3 gazelden 1'i daha önce yapılan makale çalışmasıyla yayımlanmıştır. Bu çalışmada mecmuada Hayretî mahlasıyla kayıtlı olan ve daha önce hiçbir çalışmayla yayımlanmayan 2 gazelin şekil ve muhteva özellikleri incelenerek, Hayretî Divanı'ndaki diğer şiirlerle mukayesesi yapılmıştır.
\end{abstract}

Anahtar Kelimeler: Hayretî, Hayretî Divanı, gazel, şiir mecmuası

\section{TWO UNPUBLISHED ODES OF HAYRETÎ WHO WAS ONE OF THE POETS IN 16TH CENTURY AND THE EVALUATIONS ON THESE ODES}

\begin{abstract}
16th century is a period when the significant persons of Classical Turkish literature grew up. One of the great poets in this period is Hayreti. Hayreti who was born in Varnar Yenice was the brother of Yusuf-1 Sîneçâk who was the mevlevi sheikh. Hayreti who had a mystic personality firstly initiated to Shekh İbrahim Gülşeni and then, adopted The Bektashism. Hayreti who lost his eyes to the end of his life had the reorganized divan. Mehmet Çavuşoğlu and M. Ali Tanyeri published Hayreti's Divan. According to the evaluations of writers on the collection of biographies, it is possible to see poems of Hayreti, who had the amorous, popular, plain and likable odes, on many journals and the records of public literature. While some of these poems are available on the poet's divan, some of them are not available.

When the poets' collection of biographies, historical and biographical sources have been reviewed, another divan poets with the assumed name of Hayreti who lived in 16th century have not been seen yet. There are 28 odes recorded with the assumed name of Hayreti on the journal of poem

\footnotetext{
* Doktora Öğrencisi, Niğde Ömer Halisdemir Üniversitesi, Sosyal Bilimler Enstitüsü, Türk Dili ve Edebiyatı Ana Bilim Dalı.

e-posta: kardenkarakoc@yandex.com
} 
with the number of 06 Mil Yz A 3291 in The National Library. Three of these odes are not available on Hayreti's Divan that Mehmet Çavuşoğlu and M. Ali Tanyeri prepared it. One of three odes which are not available on Hayreti's Divan was published with an article which was made previously. On this study, the form and content features of 2 odes which are not recorded with the assumed name of Hayreti on the journal and have not been published on any studies were reviewed and their comparison with the other poems on Hayreti's Divan was made.

Keywords: Hayretî, Hayreti's Divan, Ode, Journal of Poem

\section{Giriş}

16. yüzyıl, klasik Türk edebiyatının en büyük şairlerinin yetiştiği dönemdir. Bu yüzyılda yaşayan en büyük şairlerden biri de Hayretî'dir. Hayretî'nin hayatı ve şahsiyetine dair bilgileri tezkirelerden ve tarihiî kaynaklardan elde etmek mümkündür. Hayretî’nin asıl adı Mehmet'tir. Osmanlı coğrafyasının önemli bir kültür merkezi olan ve çok sayıda şairin yetiştiği Vardar Yenicesi'nde doğmuştur. Mesleği sipahiliktir ve akıncı beyleriyle Üsküp, Belgrad gibi çeşitli yerlerde bulunmuştur. Eğitimi hakkında bilgi yoktur; ancak "çelebi" unvanını kullanmasına bakılarak şairin eğitim gördüğü anlaşılmaktadır. Kuvvetle muhtemel kardeşi Yusuf Sîneçâk gibi önce Gülşenî daha sonra da Bektaşî tarikatına girerek eğitimini tamamlamıştır. Ömrünün sonuna doğru gözlerini kaybetmesine rağmen şair ve şiir meclislerine katılmaya devam etmiştir. Tezkirelerde sıklıkla anlatılan bir rivayete göre Hayretî, Vardar Yenicesi'nden İstanbul'a devrin ileri gelenlerinden ihsanlar umarak gelir ve Kanuni döneminin devlet adamlarından biri olan İbrahim Paşa'ya bir kaside sunar. Bu kasideyi beğenen İbrahim Paşa, Hayretî'nin nasıl bir şair olduğunu onunla aynı memleketten olan Hayâlî Bey'e sorar. Hayâlî Bey'in onu tok gözlü ve kimseye baş eğmeyen bir kişi olarak tanıtmasından dolayı küçük bir tımarla geçiştirilir. ${ }^{1}$

Hayretî’nin yaşadığı Vardar Yenicesi, dönemin büyük şairlerinin yetiştiği, kendine has edebi iklimin ve mahallî kültürün yaşandığ 1 bir coğrafyadır. $\mathrm{Bu}$ coğrafyanın mahallî unsurları, rind ve kalender söyleyiş tarzı Hayretî'nin üslubuna yansımıştır. Ömrü boyunca tasavvufla ilgilenen ve çeşitli tarikatlara yakınlık gösteren Hayretî, şiirlerinde hem Hz. Ali ve on iki imamı hem de dört halifeyi övmüştür. Hayretî, "Ca'ferî-mezheb safâŷ̂ cânlaruz” (ÇavuşoğluTanyeri, 6. musammat, 7. beyit) dizesinde mezhebini Ca'ferî, "Hânekân-ı 'ışk içinde baş açuk Bektaşîyem " (Çavuşoğlu- Tanyeri, 306. gazel, 5. beyit) dizesinde ise Bektaşî olduğunu açıkça dile getirmektedir. "Hayretî, vahdet-i vücûda dayanan bir tasavvuf anlayışına sahiptir. $\mathrm{O}$ ilâhî aşk deryasına dalan bir rinttir. Engin ve kararsız bir gönle sahip mutasavvıflardandır. Şiirlerinde dikkat çeken tasavvuf, çoğu divan şairinin aksine, estetik kaygılardan çok, normal bir hayat tarzının yansıması olarak yer almıştır" (Tatcı, 1998b: 7).

\footnotetext{
${ }^{1}$ Hayretî’nin hayatı hakkında bilgiler için bkz. Künhü’l-Ahbâr'ın Tezkire Kısmı (İsen, 2017: 128129), Meşâ'irü'ş-şu'arâ (Kılıç, 2018: 274), Latîfî Tezkiresi (Canım, 2018: 206), Heşt Behişt (İpekten, Kut, İsen, Ayan, Karabey, 2017: 245), Gülşen-i Şu'arâ (Solmaz, 2018: 137), Hasan Çelebi Tezkiretü'ş-şu'arâ (Sungurhan, 2017: 314), Mehmed Süreyya, Sicill-i Osmani, C. 2. s. 663.
} 
Tezkirelerde Hayretî'nin şairliği övgü dolu sözlerle anlatılmıştır. Âşıkane ve insan tabiatına hoş gelen gazelleri vardır (İpekten ve vd., 2017: 246), rind-meşrep, derviş-sıfat, tasavvuf ilminde bilgili, gazelde hoş-edaya sahip bir şairdir (Solmaz, 2018: 137). Kınalızâde Hasan Çelebi ve Âş1k Çelebi ise Hayretî’nin sanattaki hünerini, sade bir dille yazmasına rağmen farklı manaları söz ustalı̆̆ıla birleştiren manasındaki "çâşnidâr" kelimesiyle ifade etmişlerdir (Sungurhan, 2017: 314, Kılıç, 2018: 274).

Hayretî samimi ve sade üslûbu, rindâne edası, zengin kelime hazinesi, çeşitli deyimler kullanması, mahallî tasvirlere ve müşahhas unsurlara yer verişiyle dikkati çeken bir şairdir. Onun âşıkane, halk zevkine uygun, sade ve hoşa giden gazelleri bulunduğu tezkire yazarlarınca ortaklaşa kabul edilmektedir. M. Fuad Köprülü'ye göre de Hayretî, şiirlerinde Rumeli şehirlerinin hususiyetlerini ve aşklarını açık ve lâubali bir tarzda terennüm eden orijinal bir şairdir. Ayrıca tasavvuf terimlerini kullanmada oldukça maharetlidir. Şiirde âhenge dikkat eden ve aruza hâkim olan şair edebî sanatlarda da başarılıdır. Onun asıl şahsiyetini ise sanatlı ve mazmunlarla yüklü şiirlerinden çok dervişâne ve rindâne yolda samimi şiirleri aksettirir. Bu özellikleriyle Hayretî derviş, rindmeşrep, mustarip ve bazan da zevkperest bir şairdir (Tatc1, 1998a: 61).

Hayretî’nin Divanı, devrinde her tabakadan insanın beğenip okuduğu 16. yüzyılın geniş, hacimli mürettep divanlarından biridir. Gelibolulu Ali'nin naklettiğine göre Hayretî Divanı'ndan, Hafiz Divanı gibi fal bakılırdı (İsen, 2017: 129). Mehmet Çavuşoğlu ve Mehmet A. Tanyeri'nin yedi nüsha üzerinden tenkitli metin olarak hazırladığı Hayretî Divanı ${ }^{2}$ tevhid ve na'tla başlamakta; 20 kaside, 35 musammat, 1 müstezad, 487 gazel ve 7 kıt'adan oluşmaktadır. Mehmet Çavuşoğlu ve Mehmet A. Tanyeri'nin tenkitli metin olarak hazırladığı Hayretî Divanı; Hayretî Divanı'nda Din ve Tasavvuf 3 , Hayretî Divanı'nda Maddî Kültür Unsurları ${ }^{4}$, Hayretî Divanı'nda Âșık ${ }^{5}$, Hayretî Divanı'nda Sevgili ve Sevgilinin Fizikî Yapısı ile İlgili Özellikleri' ${ }^{6}$, Hayretî Divanı'nda Bitkiler', Hayretî Divanı'nda Kozmik Âlem ve Zaman ${ }^{8}$, Hayretî Divanı Sözlüğ ${ }^{9}$ adlı tez çalışmalarına konu olmuştur. Ayrıca Hayretî'nin Divanı'nda bulunan veya Hayretî'nin Divanı dışında kalmış,

${ }^{2}$ Çavuşoğlu, Mehmet, M. Ali Tanyeri (1981). Hayretî Divan Tenkidli Basim, İstanbul: İstanbul Üniversitesi Edebiyat Fakültesi Yayınları.

3 Tatcı, Mustafa (1986). Hayretî Divanı'nda Din ve Tasavvuf, Yayımlanmamış Yüksek Lisans Tezi Ankara: Gazi Üniversitesi Sosyal Bilimler Enstitüsü.

${ }^{4}$ Sarı, Mehmet (1986). Hayretî Divanı'nda Maddi Kültür Unsurları, Yayımlanmamış Yüksek Lisans Tezi, Ankara: Gazi Üniversitesi Sosyal Bilimler Enstitüsü.

5 Temizkan, Mehmet (1986). Hayretî Divanı'nda Âşsk, Yayımlanmamış Yüksek Lisans Tezi, Ankara: Gazi Üniversitesi Sosyal Bilimler Enstitüsü.

${ }^{6}$ Arı, Ahmet (1987). Hayretî Divanı'nda Sevgili ve Sevgilinin Fizikî Yapısı ile İlgili Özellikleri, Yayımlanmamış Yüksek Lisans Tezi, Ankara: Gazi Üniversitesi Sosyal Bilimler Enstitüsü.

7 Öztoprak, Nihat (1986). Hayretî Divanı'nda Bitkiler, Yayımlanmamış Yüksek Lisans Tezi İstanbul: Marmara Üniversitesi Sosyal Bilimler Enstitüsü.

${ }^{8}$ Güven, Hikmet Feridun (1988). Hayretî Divanı'nda Kozmik Âlem ve Zaman, Yayımlanmamış Yüksek Lisans Tezi, İstanbul: Marmara Üniversitesi Sosyal Bilimler Enstitüsü.

${ }^{9}$ Gök, Selim (2017). Hayretî Divanı Sözlüğü (Bağlamlı Dizin ve Işsevsel Sözlük), Yayımlanmamış Doktora Tezi, Ankara: Gazi Üniversitesi Sosyal Bilimler Enstitüsü. 
mecmua ve cönklerde rastlanan şiirleriyle ilgili çeşitli makale çalışmaları da vardir.

\section{06 Mil Yz A 3291 Numaralı Mecmuanın Özellikleri}

Mecmualar, divan sahibi şairlerin divanına girmemiş şiirlerini barındırması açısından klasik Türk edebiyatının en önemli kaynakları arasındadır. Edebiyatımızda sayılarının çokluğu ve zengin muhteva özellikleriyle dikkat çeken mecmuaları Agâh Sırrı Levent şu şekilde sınıflandırmıştır:

1. Nazîre mecmuaları,

2. Meraklılarca toplanmış, birer antoloji niteliğinde seçme şiir mecmuaları,

3. Türlü konulardaki risalelerin bir araya getirilmesiyle meydana gelen mecmualar,

4.Aynı konudaki eserlerin bir araya getirilmesiyle meydana gelen mecmualar,

5. Tanınmış kişilerce hazırlanmış, birçok yararlı bilgileri, fikraları ve özel mektupları kapsayan mecmualar (Levend, 2014: 166-167).

Bu çalışmaya kaynak olan Milli Kütüphane 06 Mil Yz A 3291 numarada kayıtlı şiir mecmuasında şiirler sıralanırken belirli bir düzen yoktur; ancak yer yer nazire şiirler, zemin şiir ve nazire şiir belirtilmeksizin arka arkaya sıralanmıştır. $\mathrm{Bu}$ bakımdan mecmuanın kısmen bir nazire mecmuası olduğu söylenebilir.

06 Mil Yz A 3291 numaralı mecmuanın müstensih ve istinsah tarihine ilişkin mecmua üzerinde herhangi bir bilgi yoktur. Mecmua, 74 varaktan oluşmakta ve bazı kişi isimlerinin yer aldığı şuhûdu'l-hâl ile başlamaktadır. Mecmuada 111 farklı şaire ait 365 şiir ve mahlası ve başlığı olmadığı için kime ait olduğu tespit edilemeyen 11 şiirle birlikte toplam 376 şiir bulunmaktadır. Mecmuada çoğunluğu 16. yüzyıl olmakla birlikte 14,15 ve 17. yüzyılda yaşayan şairlerin şiirlerine yer verilmiştir. Mecmuada en geç 17. yüzyılda yaşayan şairlerin şiirlerine yer verilmesi mecmuanın 17. yüzyılda tertip edilmiş olabileceği ihtimalini kuvvetlendirmektedir. Mecmuanın yazı stili baştan sona aynı olduğu için bir kişi tarafindan tertip edildiği düşünülmektedir. Müstensih her sayfada cetvel kullanmıştır. Başlıklar ve cetvel kırmızı, yazı tipi taliktir. Cetvel dışına bir gazel dışında şiir yazılmamıştır. Bazı sayfalarda diğer sayfanın hangi kelimeyle başladığını gösteren rakabe kayıtları ve karalamalar vardır. Her sayfa iki sütundan her sütun genellikle 19 satırdan oluşmaktadır. Şiirlerin büyük çoğunluğunun başında nazım şekli ve şairin adı birlikte verilmiştir. Mecmuanın sonradan yanlış ciltlenmesi nedeniyle bazı şiirlere ait parçalar farklı varaklarda yer almaktadır. Mecmuanın dili Türkçedir; Arapça ve Farsça şiirlere rastlanmaz. Aruz ve hece ölçüsü birlikte kullanılmıştır. Gazel, kıt'a, tahmis, muhammes, müseddes, müsemmen, terci-i bent, tesdis gibi çeşitli nazım şekilleriyle yazılmış şiirler vardır. Mecmuada en çok şiiri bulunan şairler 43 şiirle 1. sırada Siyâhî, 27 şiirle 2. sırada Hayretî, 25 şiirle 3. sırada Mubibbî yer almaktadır. Mecmuada Hayretî ile aynı dönemde ve coğrafyada yaşayan Usûlî, Hayâlî gibi şairlerin şiirlerine yer 
verilmiştir. Ayrıca Hayretî gibi Alevî-Şiî bir şair olan Hatâyî’nin de mecmuada şiirleri vardır.

Mecmuada şiiri bulunan şairler şunlardır: Âfitâbî, Âhî, Ahmed, Ahmedî, Amrî, Âşık, Atâyî, Bahârî, Bahrî, Bâkî, Bedî'î, Bedrî, Behiştî, Bilâlî, Ca'ferî, Celâlî, Cemâlî, Cinânî, Dâ'î, Derûnî, Emrî, Enverî, Fakîrî, Fazlî, Fendî, Fenâyî, Fevrî, Figânî, Firâkî, Fünûnî, Gedâyî, Gulâmî, Halîlî, Harîmî, Hatâyî, Hâverî, Hayâlî, Haydaroglu, Hayretî, Hisâlî, Hüsrev, İbâdî, İlmî, İshâk, İşretî, Kâdî, Kalender, Karînî, Kâtibî, Kerîmî, Lutfî, Mahremî, Me'âlî, Medhî, Mesîhî, Mu'îdî, Mu'înî, Muhibbî, Muhlîsî, Mûyî, Mutî'̂̂, Münîrî, Na'îmî, Nagmî, Nâmî, Nazmî, Necâtî, Nesîmî, Nev'î, Nihâlî, Nihânî, Nizâmî, Nutkî, Penâhî, Rahmî, Re’yi, Revânî, Rûhî, Rumûzî, Sadâyî, Sâdıkî, Sâ'yî, Sebâtî, Selîkî, Semâ'î, Seyrî, Siyâhî, Sun'̂̂, Sücudî, Şâh Tahmâs, Şâlî, Şehîdî, Şem'î, Şemsî, Şeyhî, Şîrâzî, Tâcirî, Ubeydî, Ulvî, Usûlî, Ümîdî, Vahdetî, Vâlihî, Visâlî, Vusûlî, Yahyâ, Yemînî, Zâtî, Zemînî, Zeynî ve Zuhûrî' dir.

Mecmualarda şairlerin divanlarına girmemiş şiirleri bulunabilmektedir. Bir şaire ait şiirlerin o şairin divanında yer almamasının sebeplerini Yaşar Aydemir şu şekilde siralar:

- Divan neşirlerinde yer almadığı halde mecmualarda bulunan bir şiir, metin tenkiti yapılan çalışmalarda görülemeyen nüshalardan kaynaklanmış olabilir.

- Şair, divanını tertip ettikten sonra şiir yazmış, yazdığı bu şiir tertip ettiği divan nüshasına girmemiş olabilir. Ömrü vefa etmediği ya da başka sebeplerle tekrar tertibe girişemediği için bu şiir dışarıda kalmıştır.

- Divan şiiri büyük oranda meşk etme, egzersiz yapma üzerine kuruludur. Meşk edilen bu şiir, bir anlamda karalamadır ve şair divanına girmesini istememiş olabilir.

- Şair, meşk ettiği çalışmaların hepsini değil en güzelini divan tertibine almak istemiş olabilir. Bazı çift matlalı gazel örnekleri buna delil teşkil edebilir.

- Şair, bazı şiirlerini estetik açıdan yetersiz gördüğü veya çalışmasını tamamlama noktasında eksik kaldığını düşündüğü için divan tertibine almamış olabilir.

- Şair, divanını kendisi tertip etmemiş, sonradan bir başkası tarafindan tertip edilmiş, böylelikle bazı şiirleri tertip dışında kalmış olabilir.

- Bazı şairlerin müsveddeleri ölümünden sonra yayılmış olabilir.

-Bazı şairlerin, özellikle çok okunan şiirlerinin dilden dile dolaşması sonucu, bir anlamda miri malı olarak görülen ve zamanla aslından uzaklaşan ikinci bir manzume olarak ortaya çıkmış olabilir(Aydemir, 2007:132-133).

06 Mil Yz A 3291 numaralı mecmuada divan sahibi şairlerin divanları dışında kalmış şiirleri ilgili daha önce yapılan çalışmalar vardır. Bu çalışmalardan birinde 
Muhibbî’nin 24 gazel, 1 müseddes, 1 tahmisi makale çalışmasıyla yayımlanmış ${ }^{10}$ ve makaleden sonra bu şiirler Muhibbî Divanı'nın ikinci cildine ${ }^{11} 06$ Mil Yz A 3291 numaralı mecmua kaynak gösterilerek eklenmiştir. Bir başka çalışmada Seyrî'nin 1 gazeli yine bu mecmua kaynak gösterilerek Seyrî Divanı'na eklenmiştir. ${ }^{12}$ Mecmuadaki Şah Tahmas ve Şah Süleyman'ın gazel nazım şekliyle birbirlerine yazdıkları mektup tarzındaki şiir iki farklı makaleye konu olmuştur. ${ }^{13}$ İki makalede de Şah Süleyman mahlaslı şairin Kanuni Sultan Süleyman olduğu belirtilmiştir; ancak Şah Süleyman mahlaslı gazel Muhibbî Divanı'nda yoktur. Divan sahibi şairlerin divanı dışında kalmış şiirlerinin bazılarının 06 Mil Yz A 3291 numaralı mecmua kaynak gösterilerek yayımlanmasından sonra söz konusu şairlerin divanlarına eklenmesi mecmuanın değerini artırmakta birlikte diğer çalışmalara da örnek teşkil etmektedir.

06 Mil Yz A 3291 numaralı mecmuada olduğu gibi araştırmalardan elde edilen verilerin zaman zaman kimi şairlerin mevcut divanlarına/divançelerine eklendiği görülmektedir. Gıynaş (2011: 248-249)'ın verdiği bilgilere göre "Behiştî14, Amrî15 ve Vasfî́ ${ }^{16}$ 'nin divanları ve Figân ${ }^{17}{ }^{\text {' }}$ nin divançesi, Basîrî1 ${ }^{18}$, Haydar Cemil Baba ${ }^{19}$ Aydınlı Visâlî́ ${ }^{20}$ ve Selîkîn ${ }^{21}$ nin şiirleri mecmuaların katkısıyla neşredilmiş çalışmalardır.

06 Mil Yz A 3291 numaralı mecmuada divan sahibi şairlerin divanı dışında kalan şiirlerinin başka mecmualarda aynı mahlasla kayıtlı oldukları tespit edilmiştir. Örneğin; 06 Mil Yz A 3291 numaralı mecmuanın 30b varağında "Nesîm mahlasıyla kayıtlı gazel M. Fatih Köksal'ın şahsi kütüphanesindeki mecmuada da "Nesîmî" mahlasıyla kayıtlıdır. ${ }^{22}$ Mecmuanın $41 \mathrm{~b}$ varağındaki "Nesîm̂̂"

${ }^{10}$ Kesik, Beyhan, Zehra Pehlivan, Emre Şengül (2015). "Bir Şiir Mecmuasından Hareketle Muhibbî’nin Yayımlanmamış Şiirleri”, International Journal of LanguageAcademy. V. 3/1, s.361373.

${ }^{11}$ Yavuz, Kemal, Yavuz, Orhan (2016). Muhibbî Dîvânı Bütün Şiirleri (İnceleme-Tenkitli Metin), İstanbul: Bilnet Matbaacilık.

${ }^{12}$ Gökkaya, Recep (2017). 16. Asır Şairlerinden Seyrî ve Dîvân’l, Yayımlanmamış Yüksek Lisans Tezi, Isparta: Süleyman Demirel Üniversitesi Sosyal Bilimler Enstitüsü.

${ }^{13}$ Çınarcı, Mehmet Nuri (2015). "Söz Meydanında İki Hükümdar: Kanunî Sulltan Süleyman'ın ve Şah Tahmasb'ın Müşâ'aresi”, Tarih Okulu Dergisi, S. 8, s187-210. Diğer çalışma Kesik, Beyhan (2015). “Kanunî’nin Şah Tahmasb’ın Gazeline Cevabı”, Sosyal Bilimler Dergisi The Journal Of Social Science, S. 2, s.203-210.

${ }^{14}$ Aydemir, Yaşar (2000). Behiştî Dîvânı, Ankara: MEB Yayınları.

${ }^{15}$ Çavuşoğlu, Mehmet (1979). Amrî Dîvan Tenkidli Basım, İstanbul: İstanbul Üniversitesi Edebiyat Fakültesi Yayınları.

${ }^{16}$ Çavuşoğlu, Mehmet (1980). Vasfî Dîvan Tenkidli Basım, İstanbul: İstanbul Üniversitesi Edebiyat Fakültesi Yayınları.

${ }^{17}$ Karahan, Abdülkadir (1966). Kanuni Sultan Süleyman Çă̆ı Şairlerinden Figani ve Divançesi, İstanbul: İstanbul Üniversitesi Edebiyat Fakültesi Yayınları

${ }^{18}$ Kartal, Ahmet (2006), Basîrî ve Türkçe Şiirleri, Ankara: Akçağ Yayınları.

${ }^{19}$ Kılıç, Filiz, Orhan Kurtoğlu, Tuncay Bülbül (2008). Deniz Ali Baba Dergâhı Postnişini Haydar Cemil Baba (Haydarî) ve Şiirleri, Ankara: GÜ Türk HAMER Yayınları.

${ }^{20}$ Mermer, Ahmet (2006). Türkî-i Basît ve Aydınlı Visâlî’nin Şiirleri, Ankara: Akçağ Yayınları.

${ }^{21}$ Zülfe Ömer (2006). On Altıncı Yüzyıl Şairi Selîkî ve Şiirleri, İstanbul: Edebiyât Yayınevi.

${ }^{22}$ Köksal, M. Fatih (2009). "Seyyid Nesîmî’nin Yayımlanmamış Şiirleri”, Türk Kültürü ve Hacı Bektaş Velî Araştırma Dergisi, S. 50, s. 77-135. 
mahlasıyla kayıtlı ve Nesîmî Divanı'nın Türkiye, Tebriz neşirlerinde bulunmayan gazel ise Hindistan'ın Haydarâbâd şehrinde bulunan Oriental Manuscripts Kütüphanesinde 1322 numaralı mecmuada da "Nesîm̂े" mahlasıyla kayıtlıdır. ${ }^{23}$ Mecmuada bir şaire ait bir şiirin başka mecmualarda da aynı mahlasla kayıtlı olması 06 Mil Yz A 3291 numaralı mecmuanın güvenilirliğini artırmaktadır.

Çalışmamıza kaynak oluşturan Milli Kütüphane 06 Mil Yz A 3291 numarada kayıtlı şiir mecmuasında Hayretî mahlasıyla kayıtlı 27 gazel vardır. "Siyâhî̀" mahlaslı bir şairin Hayretî'nin bir gazeline yazdığı tahmisteki gazelle birlikte mecmuada Hayretî'ye ait gazel sayısı 28'e çıkmaktadır. Bu tahmis mecmuanın $19 \mathrm{~b}$ varağındadır ve Hayretî’nin gazeli Mehmet Çavuşoğlu ve M. Ali Tanyeri'nin hazırladığı Hayretî Divanı'nında mevcuttur. (Hayretî Divanı, 93. Gazel). Çalışmamız Mehmet Çavuşoğlu ve M. Ali Tanyeri’nin hazırladığı Hayretî Divanı esas alınarak oluşturulmuştur. ${ }^{24}$

Tablo 1: 06 Mil Yz A 3291 Numaralı Mecmuada Hayretînin Şiirlerinin Dăğlımı

\begin{tabular}{|l|l|l|l|l|}
\hline $\begin{array}{l}\text { Sıra } \\
\text { N. }\end{array}$ & $\begin{array}{l}\text { Mecmuadaki } \\
\text { Varak } \\
\text { Numaras1 }\end{array}$ & $\begin{array}{l}\text { Nazım } \\
\text { Şekli/ } \\
\text { Birimi }\end{array}$ & $\begin{array}{l}\text { Tezdeki Şiir } \\
\text { Numaras1 }\end{array}$ & $\begin{array}{l}\text { Şiirin Hayretî Divanı'ndaki } \\
\text { Mevcudiyeti }\end{array}$ \\
\hline 1 & $1 \mathrm{~b}$ & Gazel/7 & 1 & Var (Hayretî D., 390. Gazel) \\
\hline 2 & $2 \mathrm{a}$ & Gazel/5 & 3 & Var (Hayretî D., 90. Gazel) \\
\hline 3 & $2 \mathrm{a}$ & Gazel/5 & 4 & Var (Hayretî D., 316. Gazel) \\
\hline 4 & $2 \mathrm{~b}$ & Gazel/5 & 9 & Var (Hayretî D., 251. Gazel) \\
\hline 5 & $3 \mathrm{a}$ & Gazel/5 & 10 & Yok \\
\hline 6 & $4 \mathrm{~b}$ & Gazel/5 & 21 & Var (Hayretî D., 338. Gazel) \\
\hline 7 & $8 \mathrm{a}$ & Gazel/5 & 43 & Var (Hayretî D., 31. Gazel) \\
\hline 8 & $8 \mathrm{a}$ & Gazel/5 & 44 & Var (Hayretî D., 44. Gazel) \\
\hline
\end{tabular}

\footnotetext{
${ }^{23}$ Kalyon, Filiz (2015). “Nesîmî’nin Dîvânı'nda ve Diğer Kaynaklarda Rastlanmayan Şiirleri”, Turkish Studies, V10/16, s. 783-806.

${ }^{24}$ Çavuşoğlu, Mehmet, M. Ali Tanyeri (1981). Hayretî Divan Tenkidli Basım, İstanbul: İstanbul Üniversitesi Edebiyat Fakültesi Yayınları.

${ }^{25}$ Detaylı bilgi için bkz. Karakoç, Karden (2019). Milli Kütüphane 06 Mil Yz A 3291 Numarada Kayıtlı Şiir Mecmuasının Transkripsiyonlu Metni ve Mecmuaların Sistematik Tasnifi Projesi'ne (Mestap) Göre Tasnifi, Yayımlanmamış Yüksek Lisans Tezi, Osmaniye: Osmaniye Korkut Ata Üniversitesi Sosyal Bilimler Enstitüsü.
} 


\begin{tabular}{|l|l|l|l|l|}
\hline 9 & $9 \mathrm{a}$ & Gazel/5 & 48 & Var (Hayretî D., 342. Gazel) \\
\hline 10 & $9 \mathrm{a}$ & Gazel/5 & 49 & Var (Hayretî D., 228. Gazel) \\
\hline 11 & $21 \mathrm{a}$ & Gazel/5 & 108 & Var (Hayretî D., 85. Gazel) \\
\hline 12 & $29 \mathrm{a}$ & Gazel/7 & 148 & Var (Hayretî D., 4. Gazel) \\
\hline 13 & $34 \mathrm{a}$ & Gazel/5 & 172 & Var (Hayretî D., 231. Gazel) \\
\hline 14 & $34 \mathrm{~b}$ & Gazel/5 & 173 & Var (Hayretî D., 235. Gazel) \\
\hline 15 & $34 \mathrm{~b}$ & Gazel/5 & 174 & Var (Hayretî D., 318. Gazel) \\
\hline 16 & $35 \mathrm{~b}$ & Gazel/7 & 179 & Var (Hayretî D., 265. Gazel) \\
\hline 17 & $35 \mathrm{~b}$ & Gazel/5 & 180 & Var (Hayretî D., 385. Gazel) \\
\hline 18 & $35 \mathrm{~b}$ & Gazel/5 & 181 & Var (Hayretî D., 248. Gazel) \\
\hline 19 & $37 \mathrm{~b}$ & Gazel/5 & 194 & Yok \\
\hline 20 & $38 \mathrm{~b}$ & Gazel/7 & 199 & Var (Hayretî D., 35. Gazel) \\
\hline 21 & $39 \mathrm{a}$ & Gazel/5 & 200 & Var (Hayretî D., 174. Gazel) \\
\hline 22 & $39 \mathrm{a}$ & Gazel/5 & 201 & Var (Hayretî D., 305. Gazel) \\
\hline 23 & $39 \mathrm{~b}$ & Gazel/5 & 204 & Var (Hayretî D., 118. Gazel) \\
\hline 24 & $50 \mathrm{~b}$ & Gazel/5 & 253 & Var (Hayretî D., 1. Gazel) \\
\hline 25 & $51 \mathrm{a}$ & Gazel/5 & 254 & Yok \\
\hline 26 & $51 \mathrm{a}$ & $51 \mathrm{a}$ & 255 & Var (Hayretî D., 28. Gazel) \\
\hline 27 & 256 & Var (Hayretî D., 30. Gazel) \\
\hline
\end{tabular}

Yukarıdaki tabloda ayrıntılı bir şekilde gösterilen bu gazellerin büyük çoğunluğu Hayretî Divanı'nda mevcuttur ve araya başka şairlerin şiirleri gelerek karışık bir şekilde sıralanmıştır. 28 gazelden 3'ü Hayretî Divanı'nda yoktur. Ayrıca bu üç gazelden hiçbiri Hayretî'nin çok sayıda şiirinin olduğu (54 şiir) “Mecma' $u$ 'n- 
Nezâ'ir' adlı mecmuada da yoktur. ${ }^{26}$, Pervane Bey Mecmuasi' ${ }^{27}$, Mecmû' atü'lLetâif ve Sandûkatü'l-Maârif ${ }^{8}$, Sultân-1 Hūbâna Münasib $E$ Ş̧ $^{\text {'âr }}{ }^{29}$ adlı mecmualarda da bu şiirlere rastlanmamıştır. Hayretî Divanı'nda bulunmayan 3 gazelden 1'i çalışmamızdan daha önce yapılan makale çalışmasıyla 06 Mil Yz A 485 numaralı mecmua kaynak gösterilerek yayımlanmıştır. ${ }^{30} 06$ Mil Yz A 485 numaralı mecmuanın 108a varağında ve makalemize kaynak olan 06 Mil Yz A 3291 numaralı mecmuanın 37b varağında Hayretî mahlasıyla kayıtlı aşağıdaki gazel Hayretî Divanı'nda yoktur. İki mecmuada da Hayretî mahlasıyla kayıtlı bu gazel ileride yapılacak tenkitli metin çalışmalarına fayda sağlamak amacıyla mukayese edilmiş ve farklılıklar dipnotta gösterilmiştir. ${ }^{31}$

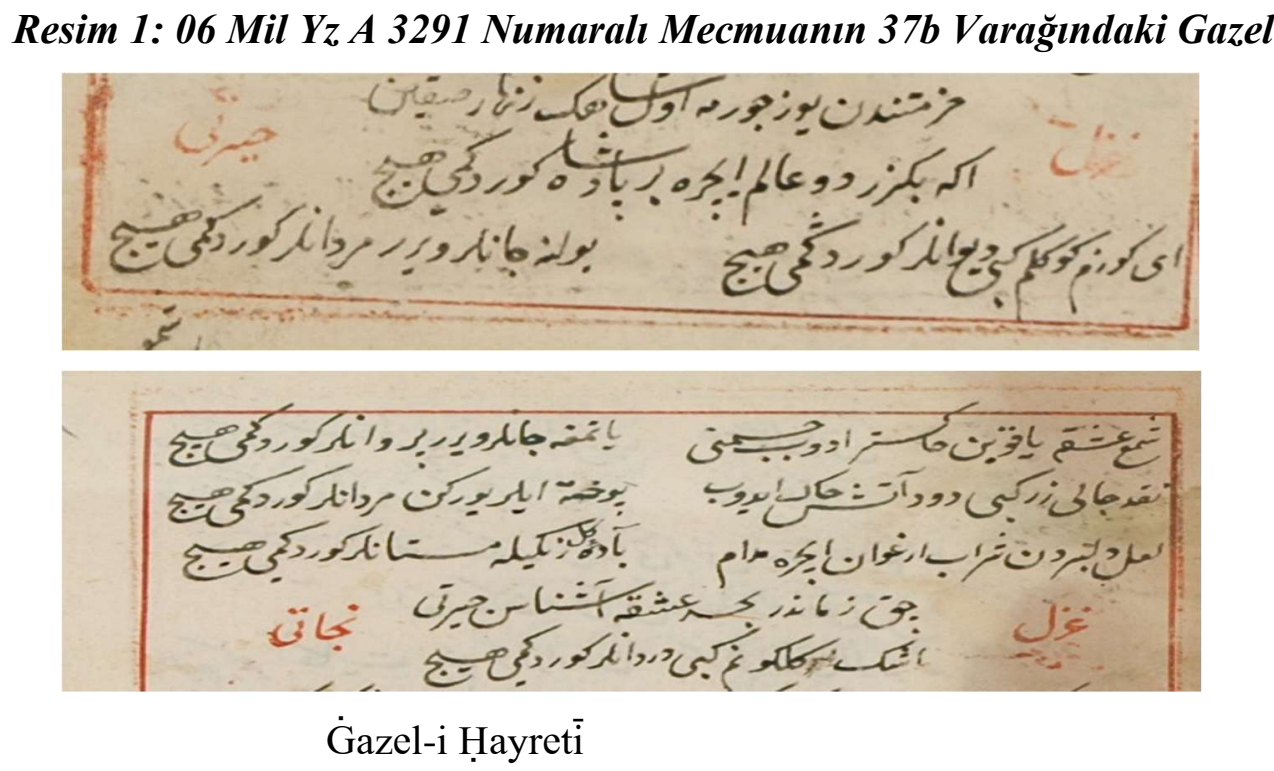

Fā'ilātün Fā'ilātün Fā'ilātün Fā'ilün

1. Ey gözüm göñlüm gibi dīvāneler gördüñ mi hịç

\footnotetext{
${ }^{26}$ Köksal, M. Fatih (2017). Edirneli Nazmî Mecma'u’n-Nezâ'ir (İnceleme- metin), Ankara: KTB. Yayınları, www.kulturturizm.gov.trhttp://ekitap.kulturturizm.gov.tr. [erişim tarihi: 10.05.2020].

${ }^{27}$ Gıynaş, Kamil Ali (2017). Pervâne Bey Mecmuası, Ankara: KTB. Yayınları, www.kulturturizm.gov.trhttp://ekitap.kulturturizm.gov.tr. [erişim tarihi: 10.05.2020].

${ }^{28}$ Gürbüz, İncinur Atik (2018). Mecmû'atü'l-Letâif ve Sandûkatü'l-Maârif (İnceleme-Tenkitli Metin-Şair ve Şiir Dizini), Ankara: KTB. Yayınları, www.kulturturizm.gov.trhttp://ekitap.kulturturizm.gov.tr. [erişim tarihi: 10.05.2020].

${ }^{29}$ Gürbüz, Mehmet (2018). Sulțân-ı Hūbâna Münasib Eş'âr (Inceleme-Metin-Şair ve Şiir Dizini), Ankara: KTB. Yayınları, www.kulturturizm.gov.trhttp://ekitap.kulturturizm.gov.tr. [erişim tarihi: 10.05.2020].

${ }^{30}$ Gök, Selim (2017a). "16. Yüzyıl Şâiri Hayretî’nin Yayımlanmamış Bir Gazeli ve Bu Gazelin Şâirin Divanındaki Gazelleriyle Mukâyesesi”, Journal of Turkish Language and Literature, V.3, 1ssue:1, s. 84-98.

31“06 Mil Yz A 3291" numaralı mecmuadaki kelime önce, "06 Mil Yz A 485" numaralı mecmuadaki kelime ise sonra gösterilmiştir. Mecmuanın aslına sadık kalınmış vezin kusurları gibi hususlarda metin üzerinde herhangi bir tasarrufta bulunulmamıştır.
} 
Yolına cānlar virür merdāneler ${ }^{32}$ gördüñ mi hịç

2. Şem` $-i$ ' aşka yaḳuban hāakister idüp ${ }^{33}$ cismini

Yanmag̉a cānlar virür pervāneler gördüñ mi hịç

3. Naḳd-i cānı zer gibi dūd-1 āteş hāk ${ }^{34}$ idüp

Puhte eyler yüregin merdāneler ${ }^{35}$ gördüñ mi hiç

4. La' 1-i dil-berden şarāb-1 erg̉avān içer müdām

Bāde-i gül-reng ${ }^{36}$ ile mestāneler gördüñ mi hīç

5. Çok zamāndur baḥr-1 ' aşḳ̂a āşināsın Hayretī

Eşk-i gülgūnum gibi dür-dāneler gördüñ mi hiç

06 Mil Yz A 3291 mecmuanın 37b varağında başlayıp ve 38a varağında biten bu şiir, gazel nazım şekliyle yazılmış ve 5 beyitten oluşmaktadır. Şiirin başlığında kırmızı renkle "Ġazel-i Hayretî" yazmaktadır. Gazelin vezni "Fâ'ilâtün Fâ‘ilâtün Fâ'ilâtün Fâ'ilün” Hayretî Divanı'nda 551 şiirden 252 adedinde kullanılmıştır. Hayretî Divanı'ndaki gazel, kaside ve musammatların \%46'sında bu vezin kullanılmıştır.

"Şairin edebi kişiliğinin tespitinde de mecmuaların önemli ölçüde katkısı vardır. Nazire mecmuaları başta olmak üzere, birçok mecmuada benzer şiirler peş peşe sıralanmıştır. $\mathrm{Bu}$ şiirlerin nazire olup olmadığ 1 mecmuaların bir kısmında belirtilmiş, bir kısmında buna gerek görülmeden benzer şiirler arka arkaya verilmiştir. Buradaki bilgilerden hareketle bir şairin üslubunu oluştururken kimlerden etkilendiğini veya kimlerin şiirlerini meşk edip egzersiz yaptığını, kimleri etkilediğini tespit mümkün hale gelmektedir" (Aydemir, 2007: 123-125). 06 Mil Yz A 3291 numaralı mecmuanın 20b varağında "Kalender" mahlaslı bir şairin gazelinden sonraki gazelin başlığında "Nazīre-i Siyāhī" yazmaktadır. Mecmuada diğer şiirlerde zemin şiir ve nazire şiir belirtilmeksizin şiirler arka arkaya sıralanmıştır. Mecmuanın 37b, 38a, 38b varaklarında aralarında

\footnotetext{
${ }^{32}$ Yolına cānlar virür merdāneler: Yā benüm cānum gibi cānāneler [06 Mil Yz A 485]

${ }^{33}$ idüp: ider [06 Mil Yz A 485]

${ }^{34}$ dūd-1 āteş hāk: ‘āşḳ āteşinde ḳāl [06 Mil Yz A 485] (06 Mil Yz A 3291 numaralı mecmuada muhtemelen eksik kelime veya ek kullanımı vardır ve bu nedenle vezin aksamaktadır.)

${ }^{35}$ Puhte eyler yüregin merdāneler: Terk-i cān eyler yürirem dāneler [06 Mil Yz A 485]

${ }^{36}$ Bāde-i gül-reng: Bāde-i rengin [06 Mil Yz A 485]
} 
Hayretî’nin söz konusu bu gazelinin de bulunduğu 5 gazel vardır. Bu gazellerden ilkinin başlığı ve mahlası yoktur. Müstensihin mecmuada bir şiirde önce zemin şiiri daha sonra nazire şiiri vermesinden hareket edersek bu gazelin zemin şiir olması kuvvetle muhtemeldir. Bu zemin şiire Hayretî, Necâtî, Gedâyî ve başlı̆̆ ve mahlası olmadığ için kimliği tespit edilemeyen bir şair nazire yazmıştır. $\mathrm{Bu}$ gazellerin sirasiyla matla' beyitleri:

Cān virür cānān yolında mübtelā gördüñ mi hiç

Yārini cāndān sever bir bì-nevā gördüñ mi hiç

Ey gözüm göñlüm gibi dīvāneler gördüñ mi hiç

Yoluña cānlar virür merdāneler gördüñ mi hiçc (Hayretî)

La' l-i nābuñ yādına mestāneler gördüñ mi hīç

Cām-1 'aşkuñ nūş ider dīvāneler gördüñ mi hịç

Cām-1 ' aşḳuñ nūş ider mestāneler gördüñ mi hịç

Yoluña cānlar virür merdāneler gördüñ mi hīç (Necâtî, Necâtî D., 39. G., s.168)

Ey gözüm miḥrāb var büt-ḩāneler gördüñ mi hiç

Huūblarla zeyn olınmış mey-ḩāneler gördüñ mi hịç (Gedâyî)

Söz konusu bu gazelin 16. yüzyıl şairlerinin çoğunlukta olduğu iki farklı mecmuada Hayretî mahlasıyla kayıtlı olması ve 06 Mil Yz A 3291 numaralı mecmuada nazire gazeller içinde yer alması bu gazelin Hayretî’ye ait olma olasılığını yükseltmektedir.

\section{Hayretî'nin Yayımlanmamış Gazelleri}

Milli Kütüphane 06 Mil Yz A 3291 numaralı mecmuada Hayretî mahlasıyla kayıtlı 28 gazelden Hayretî Divanı'nda bulunmayan 2 gazel şuana kadar hiçbir çalışmayla yayımlanmamıştır. Bu bölümde söz konusu 2 gazelin şekil ve muhteva açısından değerlendirilmesi ve Hayretî Divanı'ndaki şiirlerle mukayesesi yapılmıştır.

Resim 2: 06 Mil Yz, A 3291 Numaralı Mecmuanın 3a Vară̆ındaki Gazel 


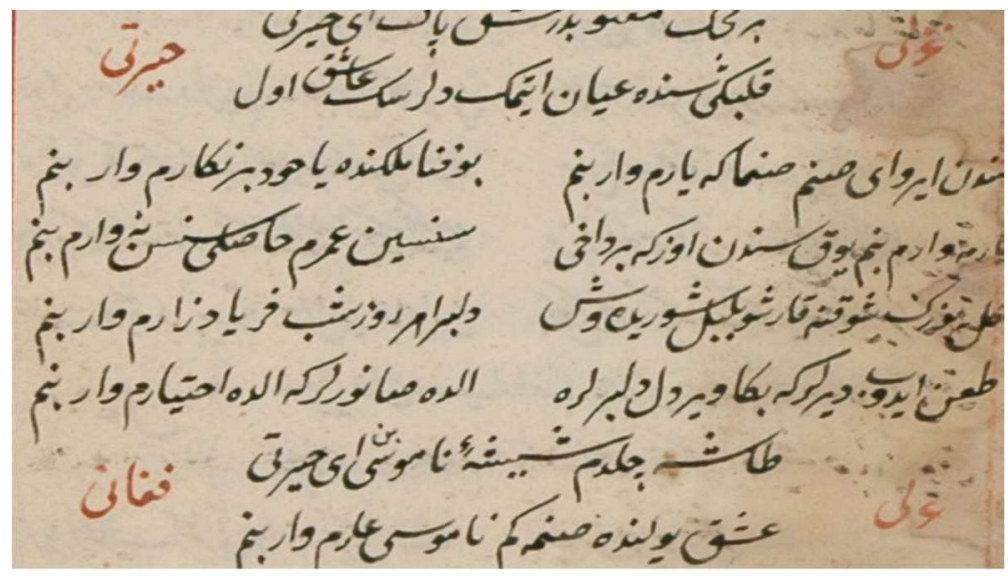

Ġazel-i Hayreti

3a Fā’ilātün Fā'ilātün Fā'ilātün Fā'ilün

1. Senden ayru ey șanem șanma ki yārum var benüm $\mathrm{Bu}$ fenā mülkinde yāhūd bir nigārum var benüm

2. Yāruma varam benüm yoḳ senden özge bir dahı Sensin ` ömrüm hạșṣlı sensin ne varum benüm

3. Gül yüzüñ şevḳine ḳarşu bülbül-i şūrīdeveş Dil-berā her rūz [u ]şeb feryād [u] zārum var benüm

4. Tạ $n$ idüp dirler ki baña vire dil dil-berlere Elde șanurlar ki elde ihtiyārum var benüm

5. Ṭaşa çaldum şiş̧e-i nāmūsı ben ey Hayretí 'Aşk yolında șanma kim nāmūs u 'ārum ${ }^{37}$ var benüm

06 Mil Yz A 3291 numaralı mecmuanı 3a varağında kayıtlı bu gazelin başlığında kırmızı renkle "Ġazel-i Hayretī" yazmaktadır. Gazelde kullanılan "Fâ'ilâtün Fâ'ilâtün Fâ'ilâtün Fâ'ilün” vezni Hayretî'nin en çok tercih ettiği vezindir. Bu vezin Hayretî Divanı'nda 551 şiirden 252'sinde kullanılmıştır. Bu oran Hayretî Divanı'ndaki şiirlerin \%46'sına tekâbül etmektedir.

Hayretî, tek harften oluşan rediflerin aksine kelime+ek, kelime+kelime, ek+birden fazla kelime şeklinde redifleri daha çok tercih etmektedir.

Tablo 3: Hayretî Divanı'nında Kullanılan Rediflerin Dă̆ılımı ${ }^{38}$

\footnotetext{
${ }^{37}$ nāmūs u ' ārum: nāmūsı ` ārum [yazma]
} 


\begin{tabular}{|l|l|}
\hline Redif Çeşitleri & Şiir Sayısı \\
\hline Ek redif & 128 \\
\hline Sözcük redif & 382 \\
\hline Ek ve sözcük redif & 189 \\
\hline
\end{tabular}

Hayretî'nin gazelinde tekrar edilen ses ve kelimeler ahengi oluşturan en önemli unsur olarak karşımıza çıkmaktadır. Hayretî, tek sesli kafiye veya redif yerine ek+kelimelerden oluşan kafiye ve redifi daha çok tercih ederek manaya ritmik bir doku kazandırmıştır. Bu gazeldeki redif ve kafiyeye Hayretî Divanı'ndan benzer örnekler ${ }^{39}$ :

Dir imişsin kullarumçün 'izz ü nâzum var benüm

Serverâ bir nâzuna yüz bin niyâzum var benüm (291/1)

Günde bin yüzden toğar bir âfitâbum var benüm

Ol sebebden tende teb cânumda tâbum var benüm (295/1)

Ta'n ider dermâna bu gönlümde derdüm var benüm

Hâlis olmış zer gibi bir rûy-1 zerdüm var benüm (296/1)

Bir gazelin redif ve kafiyesinin bir "kimseyi" veya "nesneyi" karşılıyor olması yek-ahenk şiir oluşturmada önemli bir ölçüttür. İncelediğimiz bu gazelin muhatabı "ben" zamir görevindedir ve gazelin sonuna kadar hiç değişmemektedir. Gazel boyunca muhatabın ve atıf yapılanın aynı olması gazelin yek-ahenkliği için uygun şartlar oluşturmaktadır. Hayretî Divanı'nda 487 gazelden 15 'i "sen" 25 'i ise "ben" zamirinin ek almış veya ek almamış haliyle bitmektedir. (Hayretî Divanı'nda "ben" zamiri ile biten gazellerin sira numarası: 12/ 13/ 267/ 285/ 286/ $287 / 288 / 289 / 290 / 291 / 292 / 293 / 294 / 295 / 296 / 297 / 298 / 307 / 311 / 322 / 350$ $/ 373 / 470 / 472 / 473)$

${ }^{38} \mathrm{Bu}$ tablodaki sayısal veriler için bkz. Gök, Selim (2017). Hayretî Divanı Sözlüğü (Bă̆lamlı Dizin ve İşlevsel Sözlük), Yayımlanmamış Doktora Tezi, Ankara: Gazi Üniversitesi Sosyal Bilimler Enstitüsü, s.119.

${ }^{39} \mathrm{Gazel}$ ve beyit numaraları parantez içinde gösterilmiştir. Örnek beyitler için bkz. Çavuşoğlu, Mehmet, M. Ali Tanyeri, (1981). Hayretî Divan Tenkidli Basım, İstanbul: İstanbul Üniversitesi Edebiyat Fakültesi Yayınları. 
Gazelin 1. ve 5. beytinde geçen "ey" nidası iki ayrı varlığa seslenilmede kullanılmıştır. Birinci beyitte "ey sanem" diye sevgiliye beşinci beyitte "ey Hayretı̂" diye şair kendisine seslenmektedir.

"Hayretî Divanı'nda bulunan gazel, kasîde ve musammatlardan toplamda \%8,16'sının ilk bendinin veya ilk beytinin "ey" nidası ile başladığı görülmüştür. Bu durum Hayretî'nin üslup hususiyetleri hakkında bazı tespitler yapmakta bize 1şık tutabilir. Aynı zamanda Hayretî'nin çağdaşı bazı şairlerin gazel, kasîde veya musammatlarının ilk kelimesinde "ey" nidâsı kullanma oranları mukayese edilebilir. Örneğin Bâkî Dîvânı'nın \%1,73'ünde; Hayâlî Dîvânı'nın \% 2,71'inde, Usûlî Dîvânı'nın \%5,2'sinde manzumeye “ey" nidası ile başlanmıştır. Bu çerçevede örnekleri arttırmak mümkün olmakla birlikte manzumeye nida ile başlamak konusu başka bir araştırma ile derinlemesine irdelenebilir. Ama Hayretî’nin matla“ beyitlerinde ey nidasını kullanması üslubunun bir gereği olarak karşımıza çıkmaktadır” (Gök, 2017a, 87).

Seslerin gücünü kullanmayı seven bir şair olan Hayretî’nin, "ey" nidasını kullanım açısından çağdaşı diğer şairlerle karşılaştırıldığında belirgin bir şekilde önde olduğu görülür. Şairlerin; kendilerine "ey” diye seslenerek kendilerini başka bir kişiymiş gibi tasavvur ettikleri divan şiirinde çok sık karşılaşılan bir durumdur. Hayretî, bu ifade kalıbını çok sık kullanan bir şairdir. Gazelin mahlas beytindeki "ey Hayretî" kullanımı Hayretî Divanı'nındaki 551 şiirden 127'sinde kullanılmıştır. "Ey" nidasıyla mahlasın birleştiği "Hayretiyâ" kullanımıyla bu oran daha da artmaktadır. Gazelde kullanılan "ey sanem", "ey Hayretî" kullanımına Hayretî Divanı'ndan benzer örnekler:

Ey sanem gel meded eyle işigün hastasıyuz

Niçe bir çağıralum hey meded Allâh meded (38/4)

Sen gerek lutf it gerek kahr eyle bana ey sanem

Her ne kim gelse Hudâ'dan bilürem ben hayr u şer (62/2)

Ey Hayreti kulı olan olur cihâna şâh

Sultân-1 '1şk hey ne yüce pâdişâh imiş(159/5)

İt gibi öldürmez isen ger rakîb-i kâfiri

Dime hîç ey Hayreti meydânda ben de gâzîyem (273/5)

Konuşma dilinde çokça kullanılan "sanmak" fiilinin olumsuzluk eki almış hali "sanma" ifadesini Hayretî Divanı'nında görmek mümkündür. Birinci beytin 
birinci dizesi "Senden ayru ey șanem șanma ki yārum var benüm” ve beşinci beytin ikinci dizesi "Așk yolında șanma kim nāmūs-1 'ārum var benüm” dizelerinde şair günlük konuşma dilinin samimi havasını şiirine yansıtmıştır. $\mathrm{Bu}$ kullanıma Hayretî Divanı'ndan benzer örnekler:

Ey hâce sanma sen bizi şehvet esîriyüz

Dîdâr hakkı '1şk u mahabbet esîriyüz (125/1)

Ey Hayretî ayak tozı bir kaç gedâlaruz

Biz sanma bu fenâda riyâset esîriyüz (125/5)

Pâkdür '1şkumuz ahbâb miyânında bu gün

Sanemâ sanma ki biz bûs ü kinârun kulıyuz (139/3)

“Onun şiir dilinin en güzel yanı ise halk söyleyişlerini kendi ifade kudretiyle kullanmasıdır" (Sarı, 1986: 33). Hayretî halk söyleyişlerini, atasözü ve deyimleri şiirlerine yansıtmıştır. "Hayretî’nin şiirlerinde dikkat çeken özelliklerden biri de, değişik deyimler kullanması ve yerel tasvirleri mısralarına yerleştirmesidir (Demirel, 2003: 90). Gazelde kullanılan "vire dil" (gönül vermek) deyimi Hayretî'nin şiirlerinde rastlanan bir deyimlerdir. Bu deyimlere Hayretî Divanı'ndan benzer örnekler:

'Ârif isen zînet-i dünyâ-yı dûna virme dil

Çün bilürsin kimseye yo'kdur vefâ-yı rüzgâr (118/2)

Gönül virme bu zâl-i dehre ey dil erkek ol erkek

Tek ü tenhâ yüri bir kahbeye cüft olma şâhum tek (200/1)

Aldanup her dilbere dil virme zinhâr ey gönül

Kim bulınmaz istesen dünyâyı bir yâr ey gönül (248/1)

Gördüğüm mahbûba dil virsem 'aceb mi Hayretî

Tîğ-i kahr-1 yâr ile sad pâredür gönlüm benüm (292/5)

Dil virüp cân nakdini almış metâ'-1 derdüni

Kim görüpdür bir delünün böyle bâzâr itdügin (380/5) 
Düşse pâyına sürinse yürise sâye gibi

Bir boyı serve gönül virse hevâdâr olsa (400/3)

\begin{abstract}
Abdüllbâki Gölpınarlı; "Gülşenîlik bilhassa Mevlevîlik, Bektaşîlik ve Melamîlik esaslarını da alan bu suretle tasavvuf ve melamet neşelerini birleştiren bir yoldur (Gölpınarl1, 2014: 22-23). sözüyle tarikatlar arasındaki irtibatı dile getirmektedir. "Hurûfî halifelerinin 15. yüzyılın başından Horasan, Azerbaycan ve İsfahan'da olduğu gibi Anadolu ve Balkanlar'da da hem halk hem yöneticiler arasında bir çevre edindikleri ve nihayet Kalenderîler'in arasına sızdıkları bilinmektedir" (Aksu, 1998: 411). Hayretî Divanı'nda başka şairlerin şiirlerine yazılmış iki tahmis vardır ve bunlardan biri Seyyid Nesîmî’nin diğeri Ahmed-i Sârbân'nın gazeline yazılmıştır. ${ }^{40}$ Ahmed-i Sârbân "Bayramî Melâmîliğine mensup sûfî ve şairdir. Hayrabolu'da doğmuş, cezbe sahibi bir şairdir” (Azamat, 2009: 132).

Fatih Usluer, divan şiirinde Hurufi şairler konusunu ele aldığı çalışmasında Hayretî Divanı'nından seçilmiş şiirlerinden izahlı örneklerle Hayretî'nin Hurufiliğgi benimseyen bir şair o olduğuna işaret eder. "Bir abdal olarak Hayretî'nin Hurûfîliği benimsemiş olduğu şiirlerinden anlaşılmaktadır”(Usluer, 2019: 84). Bu bilgilerden hareketle Hurûfî bir şair olan Seyyid Nesîmî'nin Hayretî üzerinde etkisi olduğu söylenebilir. Hayretî’nin gazelin makta' beytindeki “Taşa çaldum şişe-i nāmūsı" ifade kalıbı Seyyid Nesîmî’nin de şiirlerinde kullandığı bir ifade tarzıdır ve Melamîlikten izler taşımaktadır. ${ }^{41} \mathrm{Bu}$ kullanıma Hayretî Divanı'ndan benzer örnekler:
\end{abstract}

\title{
Şîşe-i 'ârı taşlara çalalum
}

Âb-1 rûy-1 fenâdan el yuyalum (330/4)

\section{Uralum taşlara gel şîşe-i nâmûsumuzı}

Ehl-i 'âr olmadan 'âşıklaruz 'âr eyleyelüm (325/2)

Kıyaslama maksadıyla incelediğimiz Taşlıcalı Yahya Divanı'nda "2 "Şı̧̧se- $i$ nâmûsu taşa çalmak/ âr u nâmusu taşa çalmak" hiç kullanılmazken Hayretî ile aynı kültür çevresinde yetişen Hayali Bey Divanı'nda ${ }^{43}$ bu ifade kalıbı kullanılmıştır.

${ }^{40}$ Çavuşoğlu-Tanyeri, a.g.e., (6. ve 7. musammat)

${ }^{41}$ Örnekler için bkz. Ayan, Hüseyin (2014). Nesîmî: Hayatı, Edebî Kişiliği, Eserleri ve Türkçe Divanı'nın Tenkitli Metni, Ankara: TDK Yayınları.

${ }^{42}$ Çavuşoğlu, Mehmet (1977).Yahyâ Bey Dîvânı, İstanbul: İstanbul Üniversitesi Edebiyat Fakültesi Yayınlar1.

${ }^{43}$ Tarlan, Ali Nihat (1945). Hayâlî Bey Dîvânı, İstanbul: İstanbul Üniveritesi Edebiyat Fakültesi Yayınlar1. 
"Hayretî, tekrir sanatını, ifade etmek istediği düşünceyi kabullendirme maksadıyla da kullanmaktadır" (Gök, 2017: 134). Gazelin ikinci beytinde "Sensin 'ömrüm hāṣıllı sensin ne varum benüm" dizesinde tekrar eden "sensin" ve dördüncü beytinde "Elde șanurlar ki elde ihtiyārum var benüm" dizesindeki "elde" kelimelerini Hayretî’nin bu amaçla kullandığını görüyoruz. Bu kullanıma Hayretî Divanı'nından benzer örnekler:

Had lâle hat benefşe eyâ yâsemen-beden

Sensin benüm bu gönlümün evvel bahârı sen (20/15)

Divan şairlerinin birçoğu asonans ve aliterasyonu kullanarak şiirde ahenk oluşturmaya gayret etmişlerdir. Hayretî' nin de şiirde ahengi artırmak için sıklıkla asonans ve aliterasyonu kullandığ 1 görülmektedir. İncelediğimiz gazelin makta' beytinde şair, "-a" sesleriyle asonans ve "-m" sesiyle aliterasyon yapmıştır:

Ṭaşa çaldum şişe-i nāmūsı ben ey Hayreti

'Așk yolında șanma kim nāmūs u 'ārum var benüm

\section{Resim 3: 06 Yz A 3291 Numaralı Mecmuanın 51a Varağındaki Gazel}

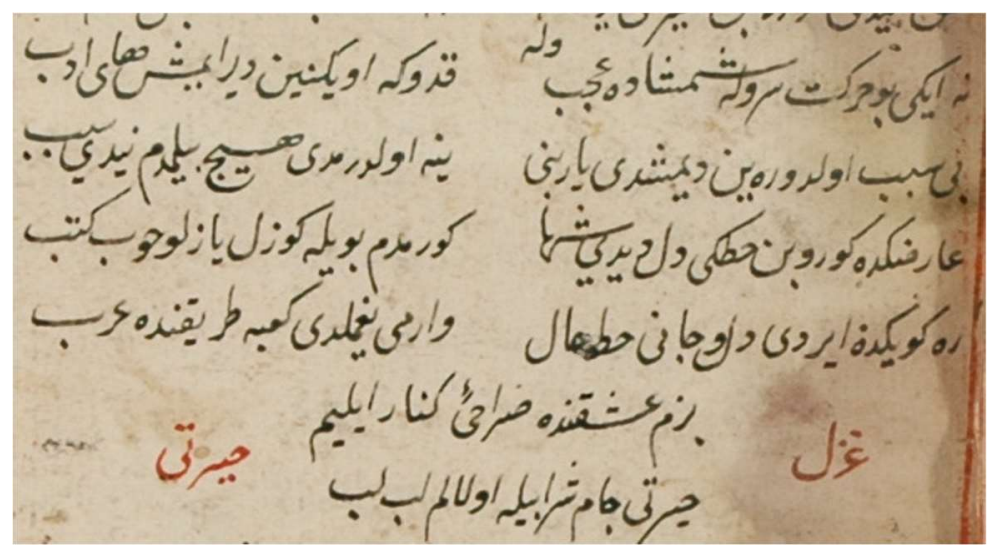

Ve lehû

$\mathrm{Fe}^{`}$ ilātün $\mathrm{Fe}^{`}$ ilātün $\mathrm{Fe}^{`}$ ilātün $\mathrm{Fe}^{`}$ ilün

1. Ne iki bu hareket serv ile şimşāda 'aceb

Kaddüñe öykineyin dir imiş hāy edeb ${ }^{44}$

Mahabbet câmın ey zâhid eline alabilmezsin

Meger kim şîşe-i nâmûsu taşa çalabilmezsin (Hayâlî Divanı, 331. Gazel,1. Beyit)

${ }^{44}$ Vezin kusurlu. 
2. B⿳亠丷⿵冂-sebeb öldüreyin dimiş idi yārini

Yine öldürmedi hiç bilmedüm ne idi sebeb

3. 'Ārıżuñda görüben ḩațuñı dil didi şehā

Görmedüm böyle güzel yazılu hūb keteb

4. Reh-i kūyuñdan ayırdı dil ü cānı ḩat u hāāl Varumı yağmaladı $\mathrm{Ka}^{\text {' }}$ be țarikininde 'Arab

5. Bezm-i ' aşkında șurāhīìi kenār eyleyem Hayretī cām-1 şarāb ile olalum leb leb

06 Mil Yz A 3291 numaralı mecmuanın 51a varağında bulunan bu gazelden sonra mecmuada yine Hayretî'ye ait gazeller vardır.

Gazelin vezni olan “ $F e^{\prime}$ ilâtün $F e^{`}$ ilâtün $F e^{`}$ ilâtün $F e^{\prime}$ ilün” Hayretî Divanı'nda 64 manzumede kullanılmıştır. Bu vezin, Hayretî'nin en çok tercih ettiği 3. vezindir ve Hayretî’nin vezin tercihiyle uyumludur.

“"Āriżuñda görüben hatțuñı dil didi şehā” dizesindeki “-uban/-üben” zarffiil eki Hayretî'nin çok sık tercih ettiği bir zarffiil ekidir ve bu zarffiil Hayretî Divanı'nda 90 kez kullanılmıştır. “Türkiye Türkçesi’nin tarihi devrinin ilkini Eski Anadolu Türkçesi teşkil etmektedir. Selçuklu devri Türkçesi'ni de içine alan bu devre XIII. asırdan XV. asrın sonuna kadar devam etmiştir. XV. asrın ikinci devresi bir geçiş devri olmakla beraber, Eski Anadolu Türkçesi'nin hususiyetleri, bütün XVI. asır boyunca devam etmiş hatta XVII. asırda da kendini göstermiştir" (Timurtaş, 1976: 331). Eski Anadolu Türkçesi'ne ait bir zarffiil ekini Hayretî’nin çok sık kullanması Hayretî’nin yaşadığı yüzyıl da göz önüne alındığında bu gazelin Hayretî'ye ait olma ihtimalini kuvvetlendirmektedir. Bu kullanıma Hayretî Divanı'ndan benzer örnekler:

Haddün yanında hat görüben didi Hayretî

Yazıldı atalar sözi Kur'ân kenarına (409/5)

Devr-i lebinde hat görüben didi Hayretî

Hızr ile geldi bir araya gûyiyâ Mesîh (34/5)

Ehl-i diller görüben hattı gubârın didiler

Kapmağa gönlini halkun gözine toz urur (73/3) 
Her nefes neydi beni ney gibi nâlân itmek

Her makâmı uyuban yad ile seyrân itmek (226/1)

"Dünyayı ve dünyevî değerleri umursamayan, içinde yaşadıkları toplumun, toplumsal düzenin inanç ve geleneklerine karşı çıkan, bunu kılık kıyafet, tutum ve davranışlarıyla gündelik hayatlarına da yansıtan sûfîlere kalender, bunların temsil ettiği tasavvufî zümrelere de genel olarak kalenderiyye veya kalenderîlik adı verilmiştir (Azamat, 2001: 253). "Varumı yagmaladı Ka'be tarikinde 'Arab" dizesindeki "varını yağmalamak" ifade kalıbı Hayretî’nin yaşamından izler taşımaktadır. İstanbul'da himaye bulamayan Hayretî, kalenderî zümresinde ve akıncı ocaklarında bir sipahi olarak hayatını sürdürmüştür. Kalenderlerin zaman zaman başına buyruk tavırları söz konusudur. Bu kullanıma Hayretî Divanı'ndan benzer örnekler:

Dil ü cân kişverin yağmaya virdi 'asker-i mihnet

Çün ol devletlü sultânumdan ayrıldum müselmânlar (74/6)

Nice olsun gönül mülki imâret

Harâmî gözlerün yağmacımuzdur (87/4)

Şakınun dil mülkini târâc iderler sakınun

Gamze-i tâtârı hûbânun katı yağmacıdur (115/3)

Ya bir alıcı laçindür ya yağmacı Moğolçîndür

Kıyar insâna bî-dîndür gözi şehlâsı İshâkun (235/3)

Gamzelerden takınup tîğini mestâne gözün

Kasdı dil mülkini yağma mı Memi Bâlîciğüm (314/3)

Kalenderîler kalp temizliğinin verdiği sarhoşlukla şer‘̂̂ sınırları aşar, farzların dışında namaz ve oruç gibi ibadetleri azaltır, şeriatın izin verdiği, dünyevî lezzetlerden mubah olanını yeme içme konusunda titizlik göstermez, bu konularda azîmet yolunun inceliklerini değil ruhsatların kolaylığını tercih ederler (Azamat, 2001: 253). Hayretî’nin tasavvufi kişiliğinin yanında zevk ve keyif verici maddelerle güzellere düşkünlüğü kalenderî yapısıyla açıklanabilir. Bu bağlamda "Bezm-i 'aşkında șurāhììi kenār eyleyem / Hayretí cām-1 şarāb ile olalum leb leb" beytinde Hayretî'nin şarap gibi zevk ve eğlence veren keyif verici maddelerle mest ve hayran olma arzusu dikkat çekmektedir. 
Şiirlerinde Rumeli şehirlerinin hususiyetlerini ve serbest aşklarını açık ve laubali bir tarzda terennüm eden Hayretî, çok orijinal bir şairdir (Köprülü, 2003: 397). Rumeli coğrafyası, duygu dünyasını ifade eden kendine has söylemlerin olduğu bir yöredir. $\mathrm{Bu}$ bölgede yaşayan şairlerin ortak bir ses dünyası ve olaylar karşısında kullandıkları ünlem ve hitaplar bulunmaktadır. "Rumeli'de samimi bir söyleyiş, senli-benli ve belki biraz da laubali bir hitap kullanımı yoğunluktadır" (Çeltik, 2013:181). Gazelin birinci beytinin ikinci dizesindeki "Kaddüñe öykineyin dir imiş hāy edeb" dizesindeki günlük hayatta şaşkınlık ve hayret bildiren "hây" seslenme ünlemi Hayretî’nin samimi ve laubali üslubuna güzel bir örnektir. "Ne iki bu hareket serv ile şimşāda 'aceb" dizesindeki "aceb" soru zarfiyla şair sorgulama yoluyla okuyucuları şiirin mana atmosferine katmakta ve senli-benli konuşma havasıyla samimi bir söyleyiş tarzı ortaya koymaktadır.

İlk gazelde belirtiğimiz gibi Hayretî “ey” seslenme ünlemini çok sık kullanmakta çoğu zaman şiirin makla' beytine “ey” ünlemiyle başlamaktadır. Ünlemlerin yanında Hayretî'nin bağlaç ve edat kullanımı incelediğimiz iki gazelle örtüşmektedir. İncelediğimiz iki gazelde kullanılan "ile, ki/kim, yahud, dahı, -veş, u/ü" edat ve bağlaçları Hayretî Divanı'nında sıklıkla kullanılan edat ve

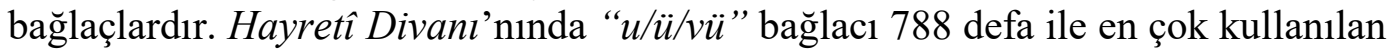
bağlaçtır. "İle” edatı ise Hayretî Divanı'nında 555 defa ile en çok kullanılan edattır. $^{45}$

\section{Sonuç}

Klasik Türk edebiyatının önemli kaynaklarından olan mecmualar; şairlerin bilinen şiirlerinin yanında bilinmeyen şiirlerini barındırması açısından büyük öneme sahiptir. 06 Mil Yz A 3291 numaralı mecmuada bilinmeyen veya divanı olmayan şairlerin şiirlerinin yanında divan sahibi şairlerin divanları dışında kalmış şiirleri de vardır. Söz konusu mecmuanın şairlerin divanlarında bulunmayan şiirlerini ihtiva etmesi mecmuanın değerini artırmaktadır.

06 Mil Yz A 3291 numaralı mecmuada bir gazelin başlığı hariç 27 gazel Hayretî başlığı ve mahlasıyla kayıtlıdır. Kendinden önceki Hayretî başlıklı ve mahlaslı gazele bitişik olarak yazılan 1 gazelin ise başlığ 1 yoktur. Bu gazellerden 25'i Hayretî Divanı'nında mevcuttur. Kalan 3 gazelin ise Hayretî Divanı'nda bulunmadı̆̆ tespit edilmiştir. 3 gazelden 1'i 06 Mil Yz A 3291 ve 06 Mil Yz A 485 numaralı mecmuada kayıtlıdır. 06 Mil Yz A 3291 ve 06 Mil Yz A 485 mecmua 16. yüzyıl şairlerinin şiirlerinin çoğunlukta olduğu şiir mecmualarıdır. $\mathrm{Bu}$ gazelin şu ana kadar tespit edilen iki farklı mecmuada Hayretî mahlasıyla kayıtlı olması gazelin 16. yüzyıl şairi Hayretî’ye ait olduğu kanâatini oluşturmaktadır.

06 Mil Yz A 3291 numaralı şiir mecmuasının 3a ve 51a varağında Hayretî mahlasıyla kayıtlı ve Hayretî Divanı'nda bulunmayan iki gazel; Hayretî Divanı ve

${ }^{45}$ Hayretî Divanı'nda ünlem, edat ve bağlaçların kullanım sıklığı için bkz. Gök, Selim (2017b). Hayretî Divanı Sözlügü (Bağlamlı Dizin ve İşlevsel Sözlük), Yayımlanmamış Doktora Tezi, Ankara: Gazi Üniversitesi Sosyal Bilimler Enstitüsü, s. 134. 
yararlanılan diğer kaynaklar ışığında incelendiğinde bu gazellerin şekil, muhteva ve ahenk özellikleri yönünden 16. yüzyıl divan şairi Hayretî’nin şiirleriyle müşterek yanlarının olduğu görülmüştür.

Mecmuanın 3a varağındaki gazelin vezni "Fâ‘ ilâtün Fâ‘ilâtün Fâ‘ilâtün Fâ‘ilün" Hayretî Divanı'nda en çok kullanılan vezindir. 51a'daki gazelin vezni " $F e^{\prime}$ 'ilâtün $F e^{\prime}$ ilâtün Fe'ilâtün Fe'ilün" ise Hayretî'nin Divanı'nda kullanım sıklı̆̆ açısından 3. sıradadır. Bu bağlamda 2 gazelin vezni Hayretî’nin vezin tercihleriyle uyumludur.

Hayretî'nin kafiye ve redif oluşturma tercihinin (ek+kelime) mecmuanın $3 \mathrm{a}$ varağındaki gazelle benzediği görülmüştür. Zîrâ Hayretî, tek sesten oluşan kafiye ve rediflerin yerine ek+kelimeden oluşan redif ve kafiyeleri daha çok tercih etmektedir.

51a'daki gazelde Eski Anadolu Türkçesinde kullanılan ve arkaik bir ek olan uban/-üben zarffiil ekini Hayretî'nin sıklıkla tercih etmesi Hayretî’nin yaşadığ1 yüzyıl da göz önünde bulundurulduğunda bu gazelin Hayretî’ye ait olma olasılığını yükseltmektedir.

37b, 3a ve 51a'daki gazellerin beyitlerinde kullanılan edat, bağlaç ve ünlemlerin (ey, ile, u/ü mi, ki, yahud, dahı) Hayretî Divanı'nındaki şiirlerle anlam ve kullanım bakımından benzerlik gösterdiği tespit edilmiştir.

Hayretî'nin ahenk oluşturma unsurlarından asonans, aliterasyon ve kelime tekrarlarını kullanımının 3a, 51a' daki gazellerle benzediği görülmüştür.

Tezkireler ve biyografik kaynaklar tarandığında 16. yüzyılda yaşamış Vardar Yeniceli Hayretî dışında "Hayret̂̀" mahlasını kullanan başka bir divan şairine "henüz" rastlanmamıştır.

06 Mil Yz A 3291 numaralı mecmuanın 3a ve 51a varağındaki gazellerin Hayretî Divanı'nındaki şiirlerle anlam ve şekil bakımından benzerlikler taşıması neticesinde bu iki gazelin 16. yüzyıl divan şairi Hayretî'ye ait olduğu sonucuna varılmıştır. Mecmualardan elde edilen yeni veriler Hayretî ile ilgili bilgilerin güncellenmesini sağlayacaktır.

\section{Kaynakça}

AKSU, Hüsamettin (1998). "Hurûfîlik", TDVİA, C. 18, İstanbul: TDV. Yayınları, s. 408 412, https://islamansiklopedisi.org.tr/hurufilik [Erişim tarihi:13.06. 2020]

ARI, Ahmet (1987). Hayretî Divanı'nda Sevgili ve Sevgilinin Fizikî Yapısı ile İlgili Özellikleri, Yayımlanmamış Yüksek Lisans Tezi, Ankara: Gazi Üniversitesi Sosyal Bilimler Enstitüsü.

AYAN, Hüseyin (2014). Nesîmî: Hayatı, Edeb̂̂ Kişiliği, Eserleri ve Türkçe Divanı'nın Tenkitli Metni, Ankara: TDK Yayınları.

AYDEMİR, Yaşar (2000), Behiştî Dîvânı, Ankara: MEB Yayınları. 
AYDEMİR, Yaşar (2007). "Metin Neşrinde Mecmuaların Rolü ve Karşılaşılan Problemler", Turkish Studies/Türkoloji Araştırmaları, II (3), s. 123-133.

AZAMAT, Nihat (2001). "Kalenderiyye", TDVIA, C. 24, İstanbul: TDV. Yayınları, s. 253-256, https://islamansiklopedisi.org.tr/kalenderiyye [Erişim tarihi: 14.06.2020].

AZAMAT, Nihat (2009). "Sârbân Ahmed", TDVİA, C. 36, İstanbul: TDV. Yayınları, s.132, https://islamansiklopedisi.org.tr/sarban-ahmed [Erişim tarihi: 14.06.2020].

CANIM, Ridvan (2018). Tezkiretü'ş-Şu'arâ ve Tabsıratü'n-Nuzamâ, Ankara: KTB. Yayınları, e-kitap: http://ekitap.kulturturizm.gov.tr/Eklenti/60327,latifitezkiretussuara-ve-tabsiratun-nuzamapdf.pdf?0.[Erişim tarihi: 12.04.2020].

ÇAVUŞOĞLU, Mehmet (1979). Amrî Dîvan Tenkidli Basım, İstanbul: İstanbul Üniversitesi Edebiyat Fakültesi Yayınları.

ÇAVUŞOĞLU, Mehmet (1980). Vasfî Dîvan Tenkidli Basım, İstanbul: İstanbul Üniversitesi Edebiyat Fakültesi Yayınları.

ÇAVUŞOĞLU, Mehmet (1977). Yahyâ Bey Dîvânı, İstanbul: İstanbul Üniversitesi Edebiyat Fakültesi Yayınları.

ÇAVUŞOĞLU, Mehmet- M. Ali Tanyeri (1981). Hayretî Divan Tenkidli Basım, İstanbul: İstanbul Üniversitesi Edebiyat Fakültesi Yayınlar1, (http://groups.yahoo.com/group/metinbankasi, Dec. 31. 2004 versiyonu).

ÇELTIKK, Halil (2013). Rumeli Şairlerinin Şiir Dünyası, Ankara: Kurgan Edebiyat Yayınları.

ÇINARCI, Mehmet Nuri (2015). "Söz Meydanında İki Hükümdar: Kanunî Sulltan Süleyman'ın ve Şah Tahmasb'ın Müşâ'aresi”, Tarih Okulu Dergisi, S. 8, s.187-210.

DEMİREL, Şener (2003). “16.yüzyıl Divan Şairlerinden Hayretî ve Devriyye Benzeri Bir Gazelinin Açıklaması", Fırat Üniversitesi, Sosyal Bilimler Enstitüsü Dergisi, S.13/1, s.89-100.

GIYNAŞ, Kamil Ali (2011). "Şiir Mecmuaları Hakkında Yapılan Çalışmalar Bibliyografyası”. Selçuk Üniversitesi Edebiyat Fakültesi Dergisi, S. 25, s. 245260.

GIYNAŞ, Kamil Ali (2017). Pervâne Bey Mecmuası, Ankara: KTB. Yayınları, www.kulturturizm.gov.trhttp://ekitap.kulturturizm.gov.tr. [Erişim tarihi: 10.05.2020].

GÖK, Selim (2017a). 16. Yüzyıl Şâiri Hayretî’nin Yayımlanmamış Bir Gazeli ve $\mathrm{Bu}$ Gazelin Şâirin Divanındaki Gazelleriyle Mukâyesesi, Journal of Turkish Language and Literature, V.3, 1ssue:1, s. 84-98. 
GÖK, Selim (2017b). Hayretî Divanı Sözlüğü (Bağlamlı Dizin ve Işslevsel Sözlük), Yayımlanmamış Doktora Tezi, Ankara: Gazi Üniversitesi Sosyal Bilimler Enstitüsü.

GÖKKAYA, Recep (2017). 16. Asır Şairlerinden Seyrî ve Dîvân'l, Yayımlanmamış Yüksek Lisans Tezi, Isparta: Süleyman Demirel Üniversitesi Sosyal Bilimler Enstitüsü.

GÖLPINARLI, Abdülbaki (2014). Nesîmî, Usûlî, R̂̂hî̀ İstanbul: Kapı Yayınları.

GÜRBÜZ, İncinur Atik (2018). Mecmû'atü'l-Letâif ve Sandûkatü'l-Maârif (Inceleme-Tenkitli Metin-Şair ve Şiir Dizini), Ankara: KTB. Yayınları, www.kulturturizm.gov.trhttp://ekitap.kulturturizm.gov.tr. [Erişim tarihi: 10.05.2020].

GÜRBÜZ, Mehmet (2018). Sulțân-ı Hūbâna Münasib Eş'âr (İnceleme-MetinŞair ve Şiir Dizini), Ankara: KTB. Yayınları, www.kulturturizm.gov.trhttp://ekitap.kulturturizm.gov.tr. [Erişim tarihi: 10.05.2020].

GÜVEN, Hikmet Feridun (1988). Hayretî Divanı'nda Kozmik Âlem ve Zaman, Yayımlanmamış Yüksek Lisans Tezi, İstanbul: Marmara Üniversitesi Sosyal Bilimler Enstitüsü.

İPEKTEN, Haluk, Günay Kut, Mustafa İsen, Hüseyin Ayan, Turgut Karabey (2017). Sehî Beg Heşt Bihişt, Ankara: KTB Yayınları, https://ekitap.ktb.gov.tr/Eklenti/56165,hest-bihistpdf.pdf?0 [Erişim tarihi: 12.04.2020].

İSEN, Mustafa (2017). Künhü'l-Ahbâr'ın Tezkire Kısmı, Ankara: KTB Yayınları, https://ekitap.ktb.gov.tr/Eklenti/55739,kunhul-ahbarin-tezkirekismpdf.pdf?0 [Erişim tarihi: 12.04.2020].

KALYON, Filiz (2015). 'Nesîmî'nin Dîvânı'nda ve Diğer Kaynaklarda Rastlanmayan Şiirleri”, Turkish Studies, V10/16, s. 783-806.

KARAHAN, Abdülkadir (1966). Kanuni Sultan Süleyman Çağı Şairlerinden Figani ve Divançesi, İstanbul: İstanbul Üniversitesi Edebiyat Fakültesi Yayınları.

KARAKOÇ, Karden (2019). Milli Kütüphane 06 Mil Yz A 3291 Numarada Kayıtl SSiir Mecmuasının Transkripsiyonlu Metni ve Mecmuaların Sistematik Tasnifi Projesi'ne (Mestap) Göre Tasnifi, Yayımlanmamış Yüksek Lisans Tezi, Osmaniye: Osmaniye Korkut Ata Üniversitesi Sosyal Bilimler Enstitüsü.

KARTAL, Ahmet (2006). Basîrî ve Türkçe Şiirleri, Ankara: Akçağ Yayınları.

KESIK, Beyhan (2015). “Kanunî’nin Şah Tahmasb'ın Gazeline Cevabı”, SobiderSosyal Bilimler Dergisi / The Journal Of Social Science, S. 2, s.203-210.

KESIK, Beyhan, Zehra Pehlivan, Emre Şengül (2015). "Bir Şiir Mecmuasından Hareketle Muhibbî'nin Yayımlanmamış Şiirleri”, International Journal of Language Academy. V. 3/1, s.361-373. 
KILIÇ, Filiz, Orhan Kurtoğlu, Tuncay Bülbül, (2008). Deniz Ali Baba Dergâhı Postnişini Haydar Cemil Baba (Haydarî) ve Şiirleri, Ankara: GÜ Türk HAMER Yayınları.

KILIÇ, Filiz (2018). Meşâ'irü'ş-şu'arâ, Ankara: KTB. Yayınları, https://ekitap.ktb.gov.tr/Eklenti/59036,asik-celebi-mesairus-suarapdf.pdf?0

[Erişim tarihi: 12.04.2020].

KÖKSAL, M. Fatih (2009). "Seyyid Nesîmî’nin Yayımlanmamış Şiirleri”, Türk Kültürü ve Hacı Bektaş Velî Araştırma Dergisi, S.50, s. 77-135.

KÖKSAL, M. Fatih (2017). Edirneli Nazmî Mecma'u'n-Nezâ'ir (İncelememetin),Ankara:KTB.Yayınları,www.kulturturizm.gov.trhttp://ekitap.kulturturizm. gov.tr. [Erişim tarihi: 10.05.2020].

KÖPRÜLÜ, M. Fuad (2003). Türk Edebiyatı Tarihi, Ankara: Akçă̆ Yayınları. LEVEND, Agâh Sırrı (2014). Türk Edebiyatı Tarihi, İstanbul: Dergâh Yayınları.

Mecmua, Ankara Milli Kütüphane Yazmalar Koleksiyonu, 06 Mil Yz A 485.

Mecmua, Ankara Milli Kütüphane Yazmalar Koleksiyonu, 06 Mil Yz A 3291.

Mehmed Süreyya (1996). Sicill-i Osmani, C. 2 (haz. Akbayar, Nuri, - Seyit Ali Kahraman), İstanbul: Tarih Vakfi Yurt Yayınları.

MERMER, Ahmet (2006). Türkî-i Basît ve Aydınlı Visâlî’nin Şiirleri, Ankara: Akçağ Yayınları.

ÖZTOPRAK, Nihat (1986). Hayretî Divanı'nda Bitkiler, Yayımlanmamış Yüksek Lisans Tezi, İstanbul: Marmara Üniversitesi Sosyal Bilimler Enstitüsü.

SARI, Mehmet (1986). Hayretî Divanı'nda Maddi Kültür Unsurlarl, Yayımlanmamış Yüksek Lisans Tezi, Ankara: Gazi Üniversitesi, Sosyal Bilimler Enstitüsü.

SOLMAZ, Süleyman (2018). Gülş̧en-i Şu'arâ, Ankara: KTB. Yayınları, https://ekitap.ktb.gov.tr/Eklenti/56733, ahdi-gulsen-isuarapdf.pdf?0 [Erişim tarihi: 12.04.2020].

SUNGURHAN, Aysun (2017). Tezkîretü'ş-Şu'arâ. Ankara: KTB. Yayınları, http://ekitap.kulturturizm.gov.tr/belge/1 83504/kinalizade- hasancelebi-tezkiretussuara.html. [Erişim tarihi: 12.04.2020].

TARLAN, Ali Nihat (1945). Hayâlî Bey Dîvânı, İstanbul: İstanbul Üniversitesi Edebiyat Fakültesi Yayınları.

TARLAN, Ali Nihat (1992). Necâtî Beg Dîvânı, Ankara: MEB Yayınları.

TATCI, Mustafa (1986). Hayretî Divanı'nda Din ve Tasavvuf, Yayımlanmamış Yüksek Lisans Tezi, Ankara: Gazi Üniversitesi Sosyal Bilimler Enstitüsü.

TATCI, Mustafa (1998a). "Hayretî”, TDVIA, İstanbul: TDV Yayınları, C.17, s.6162. https://islamansiklopedisi.org.tr/hayreti. [Erişim tarihi: 05.04.2020]. 
TATCI, Mustafa (1998b). Hayretî’nin Dinî-Tasavvufi Dünyası, Ankara: Kültür Bakanlığı Yayınları.

TEMIZKAN, Mehmet (1986). Hayretî Divanı'nda Âşık, Yayımlanmamış Yüksek Lisans Tezi, Ankara: Gazi Üniversitesi Sosyal Bilimler Enstitüsü.

TİMURTAŞ F. Kadri (1976). “Küçük Eski Anadolu Türkçesi Grameri”, Türkiyat Mecmuast, C.18, s. 331-368.

USLUER, Fatih (2019). "Divan Şairleri ve Hurûfîlik”, Ankara Üniversitesi Dil ve Tarih-Coğrafya Fakültesi Türkoloji Dergisi, S. 23/1, s. 80-104.

YAVUZ, Kemal- Orhan Yavuz (2016). Muhibbî Dîvânı Bütün Şiirleri (İncelemeTenkitli Metin), İstanbul: Bilnet Matbaacılık.

ZÜLFE, Ömer (2006). On Altıncı Yüzyıl Şairi Selîkî ve Şiirleri, İstanbul: Edebiyât Yayınevi. 